\title{
Krueppel-Like Factor 2
}

National Cancer Institute

\section{Source}

National Cancer Institute. Krueppel-Like Factor 2. NCI Thesaurus. Code C162391.

Krueppel-like factor 2 (355 aa, $\sim 37 \mathrm{kDa}$ ) is encoded by the human KLF2 gene. This

protein is involved in the positive regulation of gene expression. 